\title{
Producing social nature in the Mexican countryside
}

\author{
Daniel J. Klooster
}

Department of Geography, Florida State University

\begin{abstract}
In most countries in Latin America, rural areas remain as populated as, or more populated than, in 1950. People continue to live in rural areas despite the declining economic viability of agriculture and the availability of work elsewhere. Through an application of the production of nature argument, enriched by explicit attention to the production of culture and the agency of nature, I attempt to resolve that apparent paradox. In a case study illustrating the argument, agriculture has declined in importance over several decades, while craft production and temporary, cyclical emigration has increased. Remaining agricultural activities and craft production utilize natural stocks and processes through the application of family labour, with minimal recourse to a money economy. Cyclical emigration and remittances from relatives also support the economic maintenance of rural lives. Together, these activities permit the social reproduction of households that send members to find work elsewhere. At the scale of North America, therefore, Mexican nature subsidizes the cheap reproduction of labourers working in cities and commercial agriculture in both Mexico and the United States. At the scale of the village, nature enables people to cobble together livelihoods that support households and villages. But more fundamentally, people produce culture through everyday activities of production and consumption; and so nature provides the necessary context for the productive activities that define and give meaning to what households and village communities are, and what it means to be an individual member.
\end{abstract}

\section{Translocality and globalization}

$T^{\text {he translocality }}{ }^{1}$ of people from the rural south provides a window on contemporary processes of globalization. An understanding of the effects of off-farm labour and of temporary, cyclical and remittance-generating migrations of people from the rural global south is crucial for understanding rural landscapes, the reproduction of labour amidst global capitalism, the evolution of cultural diversity and local processes of environmental change.

This facet of the geography of globalization is rarely studied and poorly understood, but an exceptional group of articles published in this journal ${ }^{2}$ demonstrates that rural livelihoods cannot be thought of independently of contemporary and historical processes of globalization. Communication and transportation infrastructures, for example, increasingly permit rural peoples to cobble together livelihoods that include periods of time labouring in faraway places at the core of global capitalism, ranging from zones of commercial agriculture in Baja California and Florida to construction sites in Mexico City and kitchens in New York City. Many hope to return some day with 
savings earned from unstable, low-wage jobs. Meanwhile, they send substantial sums of money to family members back home; migrant remittances make significant contributions to the Gross Domestic Products of many countries, and frequently exceed the amount of aid and foreign direct investment countries receive. In rural landscapes ranging from Oaxaca, México, Aguatán, Guatemala and Cañar, Ecuador, migrants pepper maize fields with new houses of concrete and brick to create a kind of 'gentrified landscape of cultivated real estate'. ${ }^{3}$ These structures are the visible evidence of substantial remittances. Such remittances contribute to rural social reproduction under globalized capitalism. ${ }^{4}$

But why do rural people bother taking up translocal livelihood strategies? Why do migrants from rural areas invest in the areas they left? Why do many return to rural areas? In this paper I argue that such questions are increasingly important. I also suggest that a 'production of nature' perspective - thickened with explicit attention to the production of culture through labour and enriched by a clearer appreciation of the agency of nature - offers valuable insights in to the rural landscapes of contemporary globalization. Because of the role translocal rural areas play in the essential process of social reproduction, this perspective also sheds light on the continued vitality of global capitalism.

I develop this argument as follows. First I summarize the political-economic context of agriculture, the prevalence of migration and the importance of remittances, especially in Latin America. Second, I describe this context in greater detail for Mexico, explaining migration and the rising importance of off-farm employment in rural areas as a result of the political economy of food and agriculture in Mexico and North America. Together, the first two sections substantiate the importance of my underlying question: why do so many rural Latin Americans remain in the countryside when so many economic signals tell them to leave and find work elsewhere? Third, I explore environmental and economic change in two villages in the highlands of central Western Mexico. ${ }^{5}$ This section illustrates villagers' choices of livelihood strategies in the constraining context of the North American political economy of agriculture. In the fourth section of the article, I apply the production of nature thesis to this material, developing a parallel production of culture concept, which helps us understand the motivations behind the participation of rural people in the activities that produce both nature and culture. I also point out the agency of nature in the village landscape produced by the North American political economy of agriculture and the labour of villagers. A penultimate section develops the implications of these observations for social reproduction and the continued vitality of global capitalism. The conclusion summarizes the argument.

\section{The globalized political economy of rural livelihood in Latin America}

As urbanization advances, geographers of Latin America have noted the declining proportion of people living in rural areas. Often overlooked, however, is the stable or growing population in rural areas. Cities are growing, but rural areas are not emptying 
out. In most countries, rural populations have increased in absolute numbers over the last 50 years (see Table 1 ).

There seems to be little economic justification for this phenomenon. Prices for many of the agricultural commodities most often produced by small farmers in Latin America have been trending downward for many years. Worldwide, trade agreements open the markets of developing countries to imports of food from the developed world, while structural adjustment policies preclude them from supporting their own agricultural sectors. Trade treaties have not removed the $\$ 300$ billion worth of subsidies that Northern economies lavish on agriculture. Such subsidies amount to more than five times what the world's rich countries expend on development aid and nearly half what they expend on the military. ${ }^{6}$

The dramatic suicide of Korean farmer Kyung Hae Lee on 11 September 2003 at the World Trade Organization (WTO) talks makes the point quite clearly that the 'WTO kills farmers', as his placard read. He killed himself to protest the trade agreements that have opened up the countryside to waves of imports that bankrupt small farmers, destroy communities and drive farmers to suicide. ${ }^{7}$

Less dramatically, emigration is a typical response to the difficulties in making a living from agriculture under current conditions in many Latin American countries. Emigration to cities and other countries generates substantial remittances. The more

TABLE 1 Rural population in selected Latin American countries (millions)

\begin{tabular}{lrrrrrr}
\hline & 1950 & 1960 & 1970 & 1980 & 1990 & 2000 \\
\hline Argentina & 5.96 & 5.44 & 5.12 & 4.86 & 4.26 & 3.85 \\
Bolivia & \multicolumn{1}{c}{195} & 2.00 & 2.55 & 3.01 & 2.93 & 2.94 \\
Brazil & 33.71 & 39.40 & 42.08 & 39.55 & 37.44 & 34.31 \\
Chile & 2.36 & 2.31 & 2.33 & 2.10 & 2.27 & 2.17 \\
Colombia & 7.39 & 8.13 & 9.12 & 10.17 & 10.75 & 10.70 \\
Costa Rica & 0.54 & 0.76 & 1.03 & 1.24 & 1.65 & 1.98 \\
Cuba & 2.98 & 3.16 & 3.42 & 3.09 & 2.67 & 2.25 \\
Dominican Republic & 1.62 & 2.30 & 2.69 & 2.82 & 3.93 & 4.37 \\
Ecuador & 2.31 & 2.89 & 3.60 & 4.22 & 4.59 & 4.70 \\
El Salvador & 1.34 & 1.60 & 2.18 & 2.69 & 2.56 & 2.82 \\
Guatemala & 2.08 & 2.68 & 3.41 & 4.18 & 5.39 & 6.91 \\
Haiti & 2.73 & 3.12 & 3.69 & 4.07 & 4.80 & 5.20 \\
Honduras & 1.11 & 1.47 & 1.85 & 2.31 & 2.90 & 3.37 \\
Mexico & 14.79 & 17.95 & 20.62 & 22.71 & 23.199 & 24.33 \\
Nicaragua & 0.69 & 0.91 & 1.06 & 1.35 & 1.81 & 2.28 \\
Panama & 0.52 & 0.65 & 0.79 & 0.99 & 1.11 & 1.23 \\
Paraguay & 0.86 & 1.16 & 1.45 & 1.81 & 2.16 & 2.41 \\
Peru & 4.67 & 5.48 & 5.75 & 6.14 & 6.82 & 7.17 \\
Uruguay & 0.94 & 0.50 & 0.50 & 0.47 & 0.29 & 0.24 \\
Venezuela & 2.6 & 2.54 & 2.95 & 2.52 & 3.14 & 3.05 \\
Latin America & 91.70 & 104.43 & 116.18 & 120.31 & 125.27 & 126.29 \\
\hline
\end{tabular}

Source: Data compiled by Mort Winsberg from ECLAC/CEPAL, Statistical yearbook for Latin America and the Caribbean (United Nations Economic Commission for Latin America and the Caribbean/United Nations Economic Commission for Latin America and the Caribbean, Santiago Chile, various years). 
than $\$ 32$ billion international migrants sent home in 2002 nearly equalled foreign direct investment and substantially exceeded development assistance. For six countries in the region, remittances accounted for more than 10 per cent of the gross domestic product (see Table 2). Remittances reach 14 per cent of adults in Ecuador, 23 per cent of adults in Central America and 18 per cent of all adults in Mexico. ${ }^{8}$ Mexico's substantial population, its high emigration rate and its proximity to the United States make it the regional leader in remittances.

TABLE 2 Migration and remittances in selected Latin American countries

\begin{tabular}{|c|c|c|c|c|c|}
\hline Country & $\begin{array}{l}\text { Net } \\
\text { migration } \\
\text { per } 1000\end{array}$ & Population & $\begin{array}{l}\text { Remittances in } \\
\text { US\$millions }\end{array}$ & $\begin{array}{l}\text { Remittances } \\
\text { as \% Foreign } \\
\text { Direct } \\
\text { Investment }\end{array}$ & $\begin{array}{l}\text { Remittances } \\
\text { as \% Gross } \\
\text { Domestic } \\
\text { Product }\end{array}$ \\
\hline Argentina & 0.62 & 38740807 & 184.00 & 5.72 & 0.18 \\
\hline Bolivia & 1.37 & 8586443 & 104.00 & 15.70 & 1.35 \\
\hline Brazil & 0.03 & 182032604 & 4600.00 & 20.32 & 1.02 \\
\hline Chile & 0 & 15665216 & - & - & - \\
\hline Colombia & 0.32 & 41662073 & 2431.00 & 104.41 & 2.96 \\
\hline Costa Rica & 0.51 & 3896092 & 134.00 & 29.54 & 0.79 \\
\hline Cuba & 1.05 & 11263429 & 1138.00 & - & - \\
\hline $\begin{array}{r}\text { Dominican } \\
\text { Republic }\end{array}$ & 3.43 & 8715602 & 2111.00 & 176.15 & 9.92 \\
\hline Ecuador & 0.52 & 13710234 & 1575.00 & 118.44 & 6.47 \\
\hline El Salvador & 3.81 & 6470379 & 2206.00 & 823.75 & 15.44 \\
\hline Guatemala & 1.71 & 13909384 & 1689.00 & 370.80 & 7.26 \\
\hline Guyana & 4.16 & 702100 & 119.00 & 212.12 & 16.77 \\
\hline Haiti & 4.03 & 7527817 & 931.00 & 32103.45 & 25.94 \\
\hline Honduras & 2.04 & 6669789 & 770.00 & 394.87 & 11.68 \\
\hline Jamaica & 5.78 & 2695867 & 1288.00 & 209.81 & 16.10 \\
\hline Mexico & 2.65 & 104907991 & 10502.00 & 42.46 & 1.65 \\
\hline Nicaragua & 1.27 & 5128517 & 759.00 & 573.70 & 36.71 \\
\hline Peru & 1.03 & 28409897 & 1265.00 & 118.89 & 2.22 \\
\hline Puerto Rico & 1.54 & 3885877 & - & - & - \\
\hline Suriname & 8.84 & 435449 & - & - & - \\
\hline $\begin{array}{l}\text { Trinidad and } \\
\text { Tobago }\end{array}$ & 10.79 & 1104209 & 59.00 & 7.07 & 0.63 \\
\hline Uruguay & 0.35 & 3413329 & & & - \\
\hline Venezuela & 0.07 & 24654694 & 235.00 & 6.82 & 0.25 \\
\hline $\begin{array}{l}\text { Notes on } \\
\text { sources }\end{array}$ & $\begin{array}{l}2003 \text { estimate } \\
\text { from CIA } \\
\text { Factbook } 2003\end{array}$ & $\begin{array}{l}\text { July } 2003 \\
\text { estimate from } \\
\text { CIA Factbook } \\
2003\end{array}$ & $\begin{array}{l}2002 \text { estimate } \\
\text { from } \\
\text { MIF-IADB } \\
2003\end{array}$ & $\begin{array}{l}2001 \text { FDI } \\
\text { from World } \\
\text { Bank } 2003\end{array}$ & $\begin{array}{l}2002 \text { GDP in US\$ } \\
\text { from the World } \\
\text { Bank's World } \\
\text { Development } \\
\text { Indicators } 2003\end{array}$ \\
\hline
\end{tabular}

Sources: Central Intelligence Agency, CIA World Factbook (2003), available at: http://www. odci.gov/cia/publications/factbook/index.htmlPPP. Inter-American Development Bank/Multilateral Investment Fund, Sending money bome: an international comparison of remittance markets, Multilateral Investment Fund, Inter-American Development Bank (2003), available at: http://www.iadb.org/mif/V2/files/MIFPagerfeb2003eng.pdf. World Bank, World Development Indicators (World Bank, 2003). Available at http://www.worldbank.org/data/dataquery.html 


\section{Rural livelihood in Mexico}

The current political economy of North American agriculture undermines the economic basis of Mexican rural life. In 1960, Mexico achieved food self-sufficiency, but then the price support for maize was frozen, slowly forcing rural Mexicans (campesinos) to seek other sources of income to supplement maize farming. Meanwhile, agricultural policy neglected rural finance systems, extension services and infrastructure, especially in rain-fed areas of peasant agriculture.?

The General Agreement on Tariffs and Trade (GATT) and the North American Free Trade Agreement (NAFTA) reinforced a decades-long trend of declining real prices for maize in Mexico. ${ }^{10}$ US maize exports to Mexico have tripled since NAFTA, and now supply a third of Mexican domestic demand. ${ }^{11}$ Starting in 1992, NAFTA gave Mexico 15 years to phase in tariff reductions and import quotas on maize, the staple food, but Mexican trade and agriculture authorities waived the import quotas and refused to collect tariffs, preferring to keep the price of maize low. Rural Mexicans pay for cheap wage policies. $^{12}$

Policy-makers in Mexico perceive peasants and their communities as obstacles to progress. In 1991, just before NAFTA took effect, the Undersecretary of Agricultural Planning declared: 'it is the policy of my government to remove half of the population from rural Mexico during the next five years' - a sentiment repeatedly reaffirmed by high-ranking agriculture officials since then. ${ }^{13}$

As agriculture declined, off-farm income from activities such as construction work, petty commerce and craft production increased. Off-farm work now accounts for more than half of family income in rural households, especially in the common property agricultural communities called ejidos and comunidades agrarias that make up about 50 per cent of Mexico's land area. ${ }^{14}$

Emigration, however, remains the principal response of rural Mexicans to the declining viability of agriculture. Large numbers of Mexicans leave their country in search of income-earning opportunities in the United States; the estimated net migration rate for Mexico is -2.77 per 1000 (Table 2).

It is not surprising that large numbers of peasants and their children are leaving the countryside to search for new opportunities elsewhere; nor is it surprising that many of them do not return to their places of origin, since there are many possibilities available to try to escape the limitations of the fields. What is surprising, however, is the large number of people who do return to their communities, the volume of resources they are transferring to these communities, and the lengths to which they are going to implement new strategies to consolidate their social and productive systems. ${ }^{15}$

Emigration out of the Mexican countryside has not drained rural areas. The number of Mexicans living in towns with populations below 2500 increased from 20.62 million in 1970 to 24.33 million in 2000 (Table 1). Much migration is temporary or cyclical, and subsidizes rural livelihoods.

In spite of opportunities elsewhere, one third ${ }^{16}$ of Mexicans continue to live in rural areas, where they exercise a kind of translocal livelihood strategy. After long periods working in Mexican cities or abroad, many return to the countryside with substantial savings to invest in land, housing and productive equipment. Remittances provide 
food, clothing, shelter and education for extended families. They also support investments in community-maintaining activities such as local public works, churches, plazas and ceremonial activities. Frequently, rural Mexicans continue to cultivate maize in small amounts. Why do people remain in a countryside where they are economically redundant? To answer such questions, it will be helpful to examine rural livelihoods in more detail, through a case study of two Mexican villages.

\section{Rural livelihood in the villages of Santa Fé and San Jerónimo}

Santa Fé and San Jerónimo, two villages along the shores of Lake Pátzcuaro, Michoacán, exemplify different strategies to cope with globalization and the declining viability of agriculture. My original research project in Santa Fé and San Jerónimo was an evaluation of deforestation and of the potential for local knowledge and scientific forestry to regulate the sustainable intensification of forest use.${ }^{17}$ During the course of several months of fieldwork during 1998 and 1999, I compiled field notes on participant observation and interviews in the villages. I accompanied woodcutters to the forest, participated in reforestation activities with community members, went squirrel-hunting and mushroom-gathering with key informants and conducted open-ended interviews in Spanish with community leaders, potters, woodcutters and returned emigrants. Although most of my informants were men, I also interviewed and observed women potters and wood-gatherers. I compiled daily field notes, using Computer Assisted Qualitative Data Analysis software to code and manage the notes. These field notes provide sufficient qualitative material to explore the production of nature/production of culture argument.

\section{The decline of agriculture}

When the geographer Donald Brand conducted research in the Lake Pátzcuaro area in 1945 , he saw a region that was roughly self-sufficient in maize and beans and wheat. ${ }^{18}$ As Francisco, ${ }^{19}$ an elderly village leader in San Jerónimo, told me, prior to 1940 people planted much more extensively than they do now. In flat places, they used ox-drawn ploughs. On the rocky hillsides, they used planting sticks. People grew beans, fava beans, peas, corn and wheat. 'No one suffered from lack of food,' he told me. 'Everybody worked. Everybody had their corn.' Many people also had small herds of cattle.

In the 1940s, the US Bracero programme recruited labourers in the area, and men from San Jerónimo started to emigrate to the US. As village authorities explained to me, the presence of even-aged stands of 40-50-year-old pine trees speaks of the influence of that guest-labour programme; those trees grow on fields abandoned after villagers left San Jerónimo to work in the US.

A localized market for maize survived for many years in the town of San Jerónimo. As Rubén recalls, 'corn was always for consumption right here in the community. It was 
sold in town. But now, there isn't anything to sell. The tortilla shops bring it in from outside.' There were no tortilla shops in San Jerónimo in 1978, when Rubén returned from a stint of work in the US, but there were several by the mid-1980s. He remembers 1982 as an important year in land abandonment, because peso devaluation made foreign work more attractive at the same time as price guarantees for maize were removed.

Older men and women in Santa Fé also remember when they produced maize and wheat and beans for eating in the household, selling in town and carrying to the regional markets in Pátzcuaro and Erongarícuaro to trade for other goods. Although they sometimes purchased food in Quiroga, the largest nearby town, there was not much grain for sale there until well after the road was built, in the 1930s. As Brand noted in $1945,{ }^{20}$ the road created new opportunities for people to seek work elsewhere and to engage in small-scale commerce of local agricultural and craft products. It also permitted the entry of cheap food from outside the region, subjecting it to the disciplining power of national policies designed to keep food cheap for urban consumers (see Figure 1).

Pottery production has long been important in Santa Fé, ${ }^{21}$ but it intensified as the viability of agriculture decreased. Seventy-five-year-old Margarita summarizes the livelihood implications of these changes:

When I was a girl, we always planted maize. We always had maize and never had to buy it. We'd sell it little by little, just to get the things we needed at home. These days, if we don't buy maize, we buy tortillas. Because of work in pottery and selling pottery, almost nobody bothers to plant.

Aerial photographs from 1960, 1970 and 1990 and a satellite image from 2000 show a progressive abandonment of agricultural lands in both communities. ${ }^{22}$

In contrast to the agricultural landscape of memory, agriculture is now the principal activity of just 4 per cent of workers in San Jerónimo and only 3 per cent in Santa Fé. The 2000 residents of San Jerónimo now cobble together a living based on temporary or cyclical migration combined with weaving straw figures. In contrast, nearly all the 4700 residents of Santa Fé make and sell wood-fired pottery, with relatively little emigration. ${ }^{23}$ Each village owns a common territory covered in maize fields and forests of pine and oak, and each maintains elaborate internal institutions for self-government, for collective action on public works and for the co-ordination of religious festivals. Most residents of both communities speak Purépecha in addition to Spanish. ${ }^{24}$

\section{Translocality in the current structure of livelihood}

Pottery permits the people of Santa Fé to labour in the company of their families, the shelter of their residential compounds and in the physical and social territory of their community. Potters consider themselves fortunate compared to their neighbours in San Jerónimo, where the lack of income-earning alternatives in the community requires long absences to work elsewhere. 'People don't leave Santa Fé because we have work [making and selling pottery]', Lucas told me. 


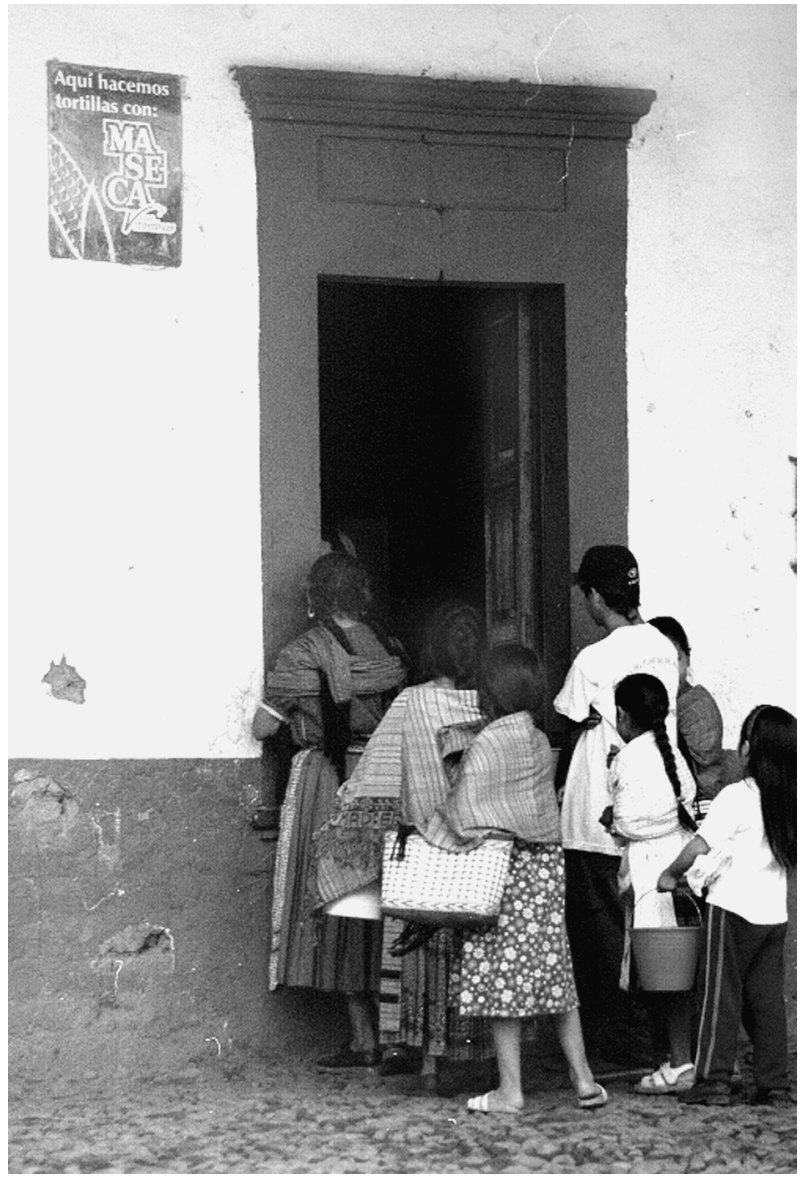

FIGURE 1 Children line up to purchase tortillas in the village plaza of Santa Fé de la Laguna, which has substantial areas of uncultivated farmland. The sign in upper left reads 'Here we make tortillas with Maseca'. Maseca is an industrialized, processed maize flour, containing imported maize.

In San Jerónimo, on the other hand, the analogous craft of weaving straw figures does not provide enough income to live on. I placed a medium-sized order for straw figures with Rudelia, paying the price she suggested of 200 pesos (about US\$20). She worked for four days on the project and used three bundles of straw for the work, each of which was purchased for 20 pesos. Her earnings, therefore, were 35 pesos a day. This contrasts with the 50 pesos a man would expect to receive for a day of labour in the fields or a construction site. I asked if she thought this was expensive or cheap, and she said neither. By selling straw figures to middlemen who visit the village, weavers earn only about 7 or 8 pesos a day. 'We don't earn anything ... You can't support yourself with this work,' she said.

Rudelia's household illustrates the way emigration, crafts and agriculture complete a translocal livelihood portfolio. There are four in her San Jerónimo household: one man 
and three women. According to Rudelia's niece, Laura, weaving straw figures is the principal occupation of the household. All the women do it. Her father's work in several hectares of land he owns is a secondary activity, and his occasional work in construction is a tertiary activity. He also owns 10 cattle. Her cousins and aunts and uncles send money from time to time and bring clothes when they visit, usually once a year. Laura's father built their comfortable house of brick and concrete, but Rudelia's brothers provided the money for the material.

Many people are in the US. If there were work here, people wouldn't leave here; they go away because there is no work here. They send us money and they bring us clothes. Ever since they left, we don't buy clothes. We support ourselves with the people who are over there. [Nos estamos ayudando con ellos que están allá. $]^{25}$

Many of the emigrants who support people like Rudelia are firmly rooted in the US now. A niece said she wants to come live in San Jerónimo, but Rudelia doubts she ever will. 'It's another life over there, and she is accustomed to it now.' Yet even so, a large number persist in returning, or at least dream of doing so soon. For example, when I asked two men in their late 20s about their emigration history and goals, they told me they had been emigrating to the US since they were 18. One has been to Chicago, where he worked in a restaurant. The other picked strawberries in Oxnard, California, and painted houses in Salem, Oregon. But they come home frequently, and invest their foreign earnings in houses in San Jerónimo. When I spoke to them, they were working on house construction. Of 866 houses in San Jerónimo, only 466 are actually inhabited. $^{26}$ Some are abandoned, but many are in a permanent state of construction by villagers who hope to return some day. 'Where do you hope to be when you are 50?' I asked the men. 'Here in San Jerónimo,' they replied.

Although emigration is much less common in Santa Fé than in San Jerónimo, it does occur. Returned emigrants might invest their saved earnings to buy a truck and to capitalize a pottery resale business, and then join the ranks of Santa Fé's relatively wealthy pottery merchants who buy from their neighbours for resale elsewhere. These merchants practise a different kind of translocality compared with emigrants. They travel long distances in their trucks to sell pottery wares in town fairs throughout central and northern Mexico, frequently returning to Santa Fé to restock, perhaps produce some pottery of their own, and to participate in village life.

José is one of the poorest potters of Santa Fé. Like several other potter households, his makes the pottery core for piñatas and sells them to a shopkeeper in Santa Fé, who resells them to a buyer in México. Compared to the glazed and painted ceramics more commonly produced in Santa Fé, piñatas don't require as much capital in glazes nor as much work gathering firewood. Without a horse or mule, José has to carry wood on his back in daily trips to gather the brush and branches he needs to fire his kiln, but he doesn't have to purchase the wood. Keeping down his cash expenditures is important to him, because when he lacks cash he must sell his production in advance to the middleman pottery merchant, and this decreases the price he might otherwise get. 'We barely have enough to get by,' he told me. 'That's why we also leave town to find work.' During the height of the rainy season, when pottery production is most difficult, 
he leaves to work in commercial agriculture or construction inside Mexico. This generates more money than making piñatas. 'There's money left over for clothing, for shoes.'

\section{A context for culture and identity}

In Santa Fé and San Jerónimo, the rights and obligations of being a comunero, a member of a common-property village, are important components of identity. When I asked Jose Luis about the obligations of being a comunero, he answered clearly and succinctly: 'Give your share of money for the saints' festivals. Participate in village meetings. Give your labour for village projects [faenas]. Serve your duties in the leadership posts the community elects you to [cargos].' These structures of community membership are widespread in Mexico: 50 per cent of the nation's territory belongs to ejidos and comunidades. Some leadership posts are inscribed in agrarian law, and many others are specific to different villages. Jaime Martínez Luna, a Zapotec intellectual from Oaxaca, calls this aspect of identity la comunalidad.

Comunalidad ... is based on labour, never on discourse. That is to say the labour of deciding [village meetings], the labour of coordination [the cargo], the labour of construction [the faena], and the labour of celebration [festivals]. ${ }^{27}$

People value communal life, and they take part in rituals that help forge their identity in the eyes of neighbours and also to themselves. These rituals involve traversing home territories, commemorating patron saints of specific neighbourhoods and making use of the products of local agriculture and wood from local forests. Through such activities, people raise their children to worship the saints and to participate in communal life (see Figure 2).

In Santa Fé, being a semanero is an important post for newly married people establishing their identity as respected members of the community. Young couples represent each of the eight barrios in Santa Fé, and they serve one week cleaning an important chapel, providing the saints in it with flowers and hosting a dinner for the people of their barrio. Dozens of relatives and neighbours help them in this task, filling the patio of the chapel with the noise of women talking and children laughing. Women clean fish, fry them in oil, make maize dough for corundas, a particular type of tamale (seasoned minced meat wrapped in dough) favoured in events such as this, mix batch after batch of chile sauce with an electric blender, and steam the corundas over a wood fire (see Figure 3). Later in the day, they will feed most of the residents of their barrio. Wood to steam the tamales and fry the fish came from the forest, gathered by their relatives. The semanera told me she and her husband spent 800 pesos on the fish, but were able to supply the maize from their own fields.

Agriculture is also an important context for the cultures of Santa Fé and San Jerónimo. Although the agricultural area has decreased in both communities, people continue intensive cultivation of an arable zone of lacustrine soils, sometimes sharecropping fields so small they are measured in surcos, or rows. Other farmers continue planting in 


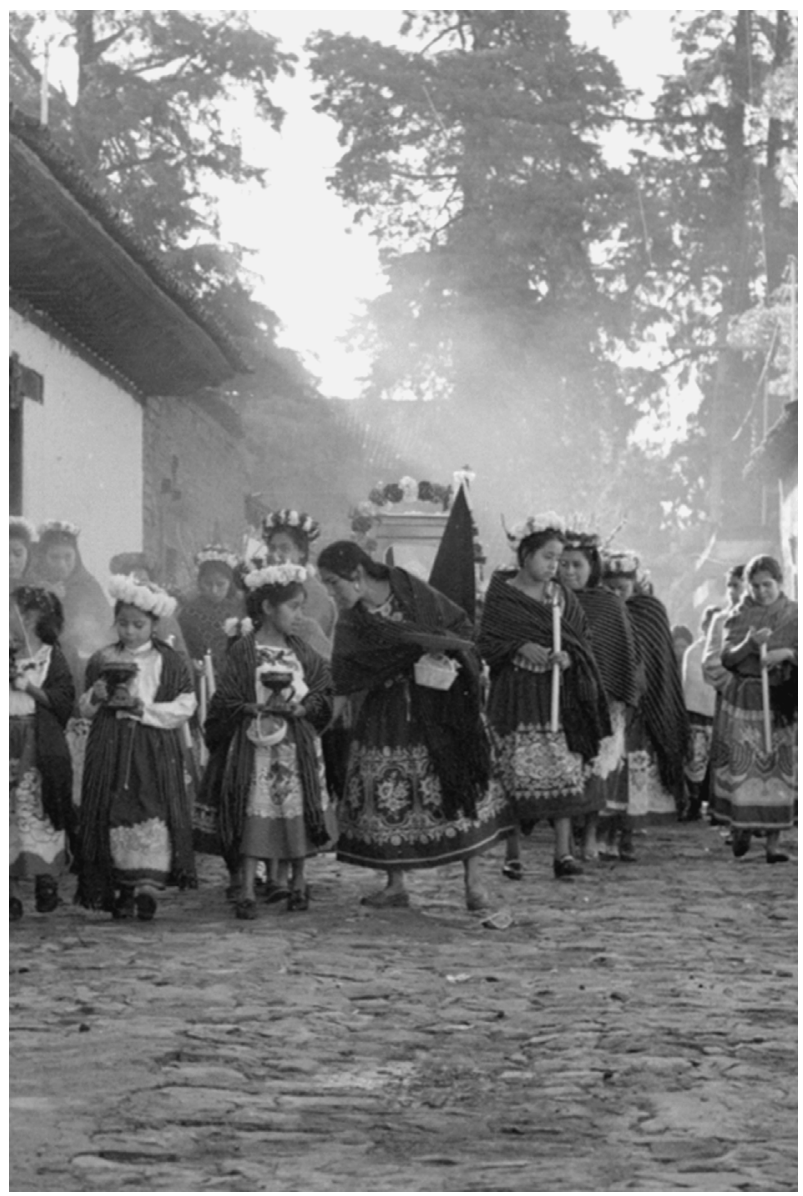

FIGURE 2 A religious procession passes through the street in Santa Fé de la Laguna toward an important chapel. Through such activities, participants cement social relationships, integrate children into the social life of the community, and link holy places in town and countryside with the physical space of streets and houses.

the highlands as well, but in fewer and smaller plots than in times past. ${ }^{28}$ Farming outside the market produces food with family labour and reduces dependence on the cash economy. Farming is also a prestigious occupation for many, and ties them into social relationships of reciprocity that also have value. Finally, it maintains agricultural biodiversity that is directly related to social and cultural reproduction. Table 3 describes some of the Purépecha terms for the main maize varieties and their major cultural uses. Tsiri urapiti, for example, is the preferred maize for corundas such as those served at semanero meals. Santa Fé farmers display their seed corn in the rafters of their houses, and take great pride in discussing their various qualities with visitors.

Serving in the role of semanero, growing corn, cutting wood, and the many other village activities of livelihood and ritual are a source of pride and self-identity. At the 


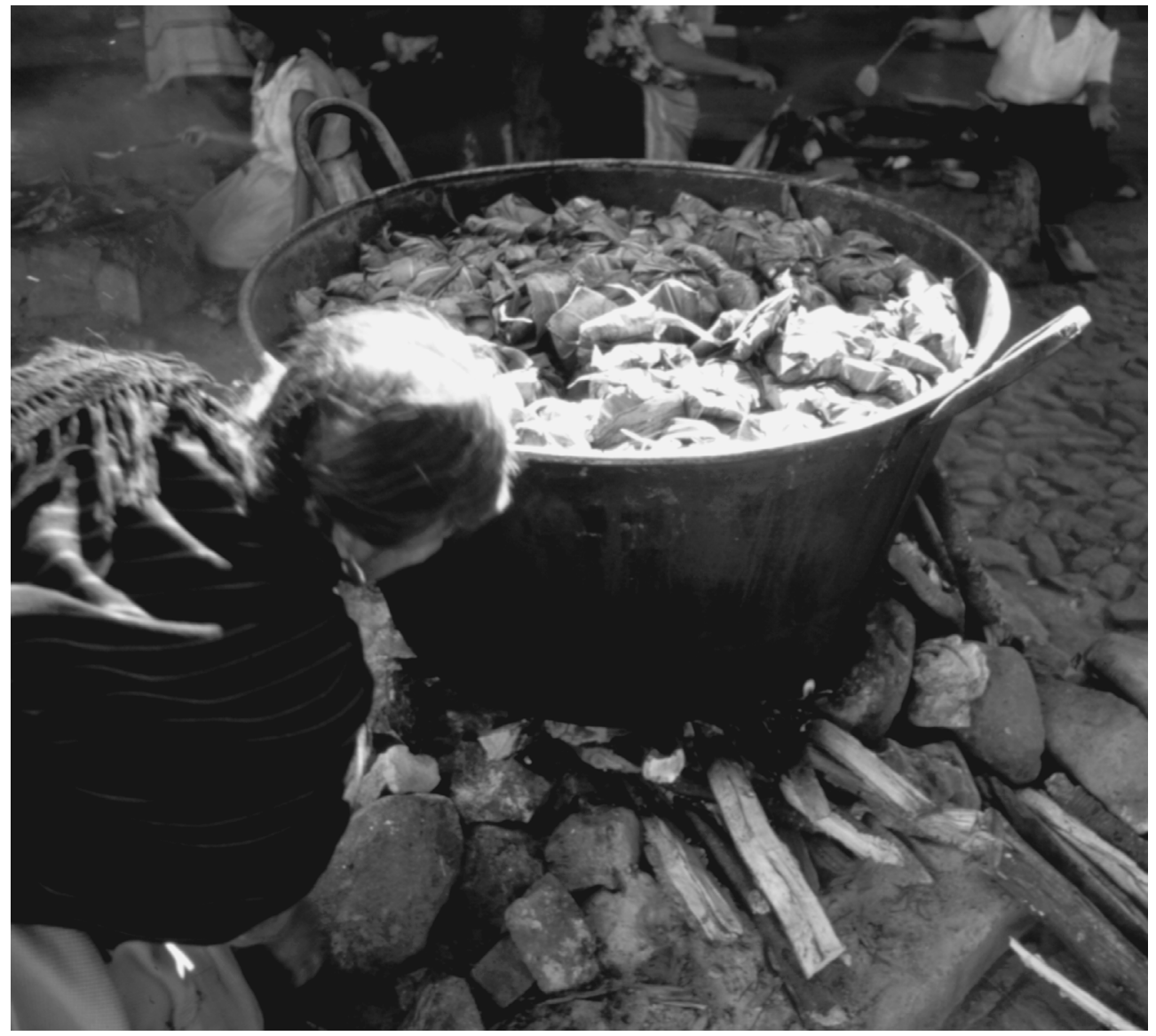

FIGURE 3 Women participate in a volunteer position (cargo), feeding corundas (specially shaped corn tamales wrapped in maize leaves) to the friends and relatives of a young couple entrusted with maintaining one of Santa Fé's most important chapels. These weekly events confirm reciprocal social relationships within the community.

same time, they are the material through which people establish their identity as individuals and convey that identity to their neighbours. In Santa Fé and San Jerónimo, production and culture are inseparable.

\section{Producing culture while producing nature}

The production of nature thesis insists that social labor rests at the heart of the social relation with nature. It rejects the notion that nature is external to human societies and it frequently identifies the logic of capitalist production systems in the choices that shape nature. It looks to production, consumption and the social relations governing these activities to understand the way human societies shape nature, and at the same time 
TABLE 3 Maize types and Purepecha cultural activities

\begin{tabular}{|c|c|c|}
\hline Maize colour & Purepecha name & Uses \\
\hline \multirow[t]{2}{*}{ White } & Tsiri sapichu & Tortillas and white atole \\
\hline & Tsiri urapiti & Tortillas and corundas (tamales) \\
\hline \multirow[t]{2}{*}{ Red } & Uaroti & Atole \\
\hline & Tsiri charapiti & $\begin{array}{l}\text { Maxkuta (hominy of red maize, beans, cilantro and chile } \\
\text { served at the Fiesta de Santiago) Tortillas with chia Uachakatas }\end{array}$ \\
\hline Yellow & Tsiri tsipambiti & Tortillas, pinole, nacatamales \\
\hline Black & Tsiri turipiti & $\begin{array}{l}\text { Berry atole, chapatas and charikurundas (tamales served } \\
\text { on Palm Sunday). Corn on the cob }\end{array}$ \\
\hline Blue & Tsiri tsirangui & Tamales \\
\hline
\end{tabular}

Source: C. Mapes, 'El maíz entre los Purépecha de la cuenca del Lago de Patzcuaro, Michoacán, Mexico', América Indiǵnena 47 (1987), pp. 345-79.

give their own societies shape. ${ }^{29}$ Proponents frequently cite the following passage from Marx:

Labour is in the first place, a process in which both man and nature participate, and in which man of his own accord starts, regulates, and controls the material re-actions between himself and nature. He opposes himself to nature as one of her own forces, setting in motion arms and legs, head and hands, the natural forces of his body, in order to appropriate nature's productions in a form adapted to his own wants. By thus acting on the external world and changing it, he at the same time changes his own nature. ${ }^{30}$

The nature that people change through labour is also their own social nature. Here I elaborate on this point, following Smith to argue that the concept of 'production' includes far more than an individual's fabrication of an object. It encompasses imaginative work, economic and cultural creation, collective endeavours and 'productive consumption by active subjects'. ${ }^{31}$ The thesis of the production of culture underscores the value of this expansive definition of production. After elaborating on the relationship between culture and production, I will examine the agency of nature in the village landscapes of Santa Fé and San Jerónimo and discuss the implications of the 'production of nature and culture' thesis for understanding periphery-core relationships in current patterns of globalization.

\section{Semiotic culture and identity}

The nature that people affect through labour is also their own social nature, including the specific cultural context in which they construct their individual identities. The everyday practices of woodcutting, tending cattle, growing maize, making pottery, preparing food, taking care of children, tending the saints and their chapels, and the various interactions with neighbours inherent in such practices - these sundry activities continually produce culture. As Clifford Geertz puts it, culture is an 'acted document', ${ }^{32}$ and an intrinsic component of the human condition, because 'man is an animal suspended in webs of significance he himself has spun'. ${ }^{33}$ As Appadurai points out, this 
semiotic definition of culture implies that Mexican villages and other such 'neighbourhoods', as he calls them, are:

contexts in the sense that they provide the frame or setting within which various kinds of human action (productive, reproductive, interpretive, performative) can be initiated and conducted meaningfully. Because meaningful life-worlds require legible and reproducible patterns of action, they are text-like and thus require one or many contexts. From another point of view, a neighborhood is a context, or a set of contexts, within which meaningful social action can be both generated and interpreted. ${ }^{34}$

Through quotidian activities and participation in significant events people produce the context in which people have meaningful lives. The great ethnographies of anthropology document the rites and rituals of the production of locality, the maintenance of webs of meaning. ${ }^{35}$

These local cultural contexts are vitally important to most of the people who live them, because they define their individual identities within them. As Geertz puts it, there is no such thing as human nature independent of culture. ${ }^{36}$ Without it, people would be 'unworkable monstrosities' with no intellect, few useful instincts or sentiments - 'mental basket cases. ${ }^{37}$

Becoming human is becoming individual, and we become individual under the guidance of cultural patterns, historically created systems of meaning in terms of which we give form, order, point, and direction to our lives. And the cultural patterns involved are not general but specific - not just 'marriage' but a particular set of notions about what men and women are like, how spouses should treat one another, or who should properly marry whom; not just 'religion' but belief in the wheel of karma, the observance of a month of fasting, or the practice of cattle sacrifice. ${ }^{38}$

As Mary Douglas puts it, people discover their identities in specific cultural contexts; the self is profoundly penetrated by community. One's identity is constituted by the community, the culture the community carries and the way it binds members of a society together. Human agents discover their ends in this context, they do not choose them in utter freedom. The community affords the means of self-discovery. "Each kind of community is a thought world, expressed in its own thought style, penetrating the minds of its members, defining their experience, and setting the poles of their moral understanding. 39

Geertz's and Douglas's observation applies equally to the residents of Mexican villages, to readers of cultural geographies and to the author of this article. One component of my identity is Assistant Professor of Geography, and one of the ways I perform that identity is by writing this peculiar essay, an essay that makes sense (hopefully) in the culture of academia. Similarly, your reading of this article carries meaning to you because of your relationship to that culture, and your own work in a community of scholars. In the same way, the people I am writing about in this article have identities enmeshed in the web of meaning they weave in their villages. They are campesino, alfarera, carguero, madre de familia. They perform those identities in a particular place, and in so doing produce small harvests of maize, a few cattle, religious sites and events and a lot of pots. They also produce a web of social relationships that reinforce their identities. 


\section{Power and cultural resistance}

The invocation of 'culture' in my argument runs the risk of miring it in an essentialist notion of culture, sinking it in the discursive quicksand of race. In efforts to avoid the wreckage of the super-organic cultural concept, Appadurai eschews the concept of culture-as-substance in favour of the adjective 'cultural', and then applies it only to the differences mobilized to define the boundaries of group identity. ${ }^{40}$ This is too narrow by far, for it dismisses too many components of the webs of meaning and denies the importance and tenacious survival of the 'neighbourhoods' and 'localities' he opposes to cultural globalization. Similarly, denying that there is such a thing as culture, except when it is constructed by class interests, as Don Mitchell would have us do, also goes too far. ${ }^{41}$ It underemphasizes the quotidian roles people play in performing the cultures that enmesh them, and it denies the role that shared cultural specificities play in establishing personal identities and communicating them to neighbours.

But Mitchell has a clear and vital purpose in claiming that there is no such thing as culture. He eschews culture in order to better theorize the workings of power in systems of social reproduction and to demystify 'cultural' resistance movements. Mitchell insists we avoid using culture in a way that hides the role of power. ${ }^{42}$

For Sidney Mintz, the material practices of consumption and production produce culture within relations of power. The cultural meanings accompanying the consumption and production of food such as sugar, for example, are imbued with history and relationships of social and economic power. What people produce and consume - and the meanings attached to those activities - depends on the choices made available to them by other actors. Power, therefore, affects people's 'self-definition by motivating their consumption, thereby entering intimately into the organization of their very personalities: who and what they think they are. ${ }^{43}$

This is clearly seen in the production and consumption of food. Food provides important strands in webs of meaning, whether for !Kung sharing game with neighbours, the semaneros sharing corundas with their neighbours in Santa Fé or for urban consumers who insist on purchasing certified organic produce.

\footnotetext{
What people eat expresses who and what they are, to themselves and to others. The congruence of dietary patterns and their societies reveals the way cultural forms are maintained by the ongoing activity of those who 'carry' such forms, whose behavior actualizes and incarnates them. Given the remarkable capacity of human beings to change, and of societies to be transformed, one must nonetheless imagine what would be involved in turning the Mexican people into eaters of black bread, the Russian people into eaters of maize, or the Chinese people into eaters of cassava. ${ }^{44}$
}

Power would be involved in such transformations. And power was involved in constraining the choices available to Mexicans, transforming many of them from growers and eaters of maize, beans, squash and amaranth into consumers of imported wheat and corn and grain-fattened beef. When they can, people resist that power by maintaining their own cultural spaces in which they can produce foods and social relationships that are important to them. In this sense, the refusal of many rural Mexicans to abandon the countryside completely should be understood as an implicit 
form of cultural resistance, a stubborn insistence on performing individual identities enmeshed in networks of social relationships, which are themselves made meaningful by particular semiotic cultures. Such people also produce nature as they go about the activities that produce culture, and nature shapes the process even as it is transformed by the process.

\section{Producing fields and forests}

Through their actions growing corn and cutting wood, villagers shape the fields and forests that surround them. They modify nature in the context of the political economy of Mexican rural livelihood, the social relations of production within their villages, and the natural processes of plant succession, soil formation and erosion.

Fragmented forests of pine and oak cover 40 per cent of San Jerónimo's and Santa Fé's common property territories, with old and active agricultural fields dispersed among tree covered areas. Forested areas frequently cover old plow furrows and stone fences. Aerial photographs from 1942, 1960, 1974 and 1990 show a process of agricultural abandonment, with old fields often swallowed up beneath vigorous stands of young trees. The oldest photos reveal a landscape with more distinct field margins, less forest cover and even greater forest fragmentation than at present. ${ }^{45}$

Even as farming decreased, however, forest use continued. Pottery production in Santa Fé is a forest-dependent activity requiring large amounts of fuelwood, preferably pine, for firing earthenware and fixing the glaze. There are 600 kilns there, with 450 in use at least twice a month. Village-wide demand for pine is conservatively estimated at $2000 \mathrm{~m}^{3}$ per year. ${ }^{46}$

Nearly all households in Santa Fé also cook with wood, preferably oak. Similarly, in San Jerónimo, 80 per cent of households use oak firewood for cooking. Villagers also use timbers from the forest for their houses and other structures. Villagers jealously guard their rights to the trees that grow in common forests and even on abandoned agricultural lands. Fuel for cooking food, firing pottery, and providing warmth comes from wood gathered freely, or purchased from a neighbour. Although propane is widely available in the region, only a minority make use of the fuel. People like the way food tastes when cooked over wood, appreciate the way a wood fire warms the kitchen, and prefer to avoid dependence on a fuel that is only available through formal markets, and whose price can change rapidly. ${ }^{47}$

The forest shows the impact of woodcutting. Cross-sectional data from forest inventories reveal marked differences in forest density and pine density between the pottery-producing town of Santa Fé, where woodcutters harvest large quantities of pine for their kilns, and San Jerónimo, where households use very little pine. On average, San Jerónimo has 250 per cent more pine per hectare than Santa Fé. A particularly accessible area of forest near the border with San Jerónimo was forested with large pines in the memory of 45-year old woodcutters. Aerial photographs from 1960, 1974 and 1990, however, show progressive thinning of pine, and Santa Fé woodcutters now frequently cut in the territory of San Jerónimo, their neighbour. ${ }^{48}$ 
This state of the forest reflects the actions of social agents who shape their culture through choices of residence and production strategies, including pottery production. ${ }^{49}$ Within Santa Fé, the specific social relations of pottery production affect the forest by inhibiting community members from developing restrictions on woodcutting. The poorest households are often forced into patron-client ties with local pottery merchants, taking out loans in exchange for the promise of future sales, selling unfinished pottery to avoid the cash outlays for glaze, or selling pottery in town, to avoid cash outlays for travel to sell elsewhere. Unfettered forest access permits potters to reduce expenditure on fuel, and so it partly compensates for the concentration of wealth within Santa Fé de la Laguna. ${ }^{50}$ The social relations of pottery production are immanent in the patterns of pine depletion.

The landscape also reflects the agency of nature. Although the political economy of North American agriculture can be said to produce abandoned fields, it does not produce the vegetation that grows on them. In many cases, these fields revert to stands of oak and pine and madrone, and closely resemble surrounding wooded areas. Depending on soil, altitude, and available seed stock, succession in such secondgrowth forests tends toward forests dominated by oak and some fir. Where erosion has impoverished soils, however, the process is stalled by stubborn thickets of Acacia spp. and Baccharis spp. These low thorny trees and tall woody shrubs make clearing very difficult, and they can impede the establishment of other trees for many years.

Where forests of pine and oak do become established, woodcutters target pine, removing them one by one without significantly opening the forest canopy or exposing mineral soils. At the same time, many of the oak species cut by woodcutters resprout from the stump. Such woodcutting is a kind of low-intensity disturbance that discourages the regeneration of pine and speeds forest succession towards oakdominated stands. ${ }^{51}$

Over the years, government-sponsored reforestation efforts have mostly failed, but in several areas serendipitous combinations of healthy seedlings, adequate soils, the timing of rainfall events and village social organization have produced pine-enriched stands of trees. Many of these semi-natural forests are approaching harvestable age, and will soon mitigate the scarcity of pine that currently forces Santa Fé woodcutters to cross the border to cut without permission in the territory of their neighbour, San Jerónimo. Already, these planted trees provide roof timbers for villagers constructing their own housing. ${ }^{52}$

\section{A subsidy from nature}

Housing is one of the ways in which the commons of Santa Fé and San Jerónimo provide important cushions against dependence on a cash economy. Each barrio in Santa Fé, for example, has lands that can be distributed to households in need of a house plot, such as the one granted to José, the piñata maker. This is something that doesn't exist in the cities, people told me, with pride. Although rarely requested, hillside land is also available for planting maize. Similarly, firewood cutting is an 
important way to avoid expense in the production process, and thus decreases exposure to obligations with local pottery buyers. Furthermore, selling firewood is an important source of occasional income for a small number of woodcutters.

People highly value these opportunities to convert labour into housing and energy without recourse to the market. I asked José, the piñata maker, why he bothered to return to Santa Fé after finding more financially rewarding work elsewhere. He explained that in part it is because of the pace of work. There, work is by shifts. 'Here, after you finish some pots, you can rest.' The main reason, however, is for 'necessity'. He has to take care of his mother. He can't take her with him because it is too expensive. You have to pay rent outside Santa Fé. Within the community, people can house themselves independently of the market.

\section{Social reproduction and global capitalism}

Rural Mexicans like the villagers of Santa Fé and San Jerónimo actively search for productive strategies that recreate aspects of a culture they value, and that allow them to continue living in their rural communities. Alternative explanations for resident rural populations in Mexico rely less on the cultural value people assign to their communities, and more on the economic difficulties migrants face in US and Mexican urban areas. These include urban congestion, pollution, crime, insecure and poorly paid labour opportunities and unavoidable expenses, such as housing. In addition, US immigration policies and language barriers discourage permanent US residence for many. Furthermore, even within Mexico, emigrants face difficulties housing and feeding extended families in cities, whereas these problems are alleviated in home communities, where housing is essentially free and where at least some food is often available without recourse to a money economy. But seeing it that way also recognizes that, at least in part, cyclical and temporary immigration patterns reflect people's desires to maintain secure spaces in which to live and reproduce. As Cindi Katz, remarks, rural Mexicans want as much control as they can muster over social reproduction: the ffleshy, messy, and indeterminate stuff of everyday life. ${ }^{53}$

At the scale of the village, nature enables people to cobble together livelihoods that support households and villages. Through community-affirming labour in nature, rural Mexicans provide themselves with food, income, lodging and social security. Simultaneously, at the scale of North America, Mexican nature subsidizes the cheap reproduction of labourers working in cities and commercial agriculture in both Mexico and the United States. In places like Santa Fé and San Jerónimo, agricultural activities and craft production utilize natural stocks and processes through the application of family labour, with minimal recourse to a money economy. This process permits the physical reproduction of households that send members to find work elsewhere.

Villagers of San Jerónimo and, to a much lesser extent, Santa Fé work in the strawberry fields of Oxnard, California, in the agricultural fields and agro-industries of central Oregon, construction in Mexican cities and in many other occupations. 'The social reproduction of a migrant workforce is carried out in its members' countries of 
origin. When they are employed elsewhere, this represents a direct transfer of wealth from generally poorer to richer countries. ${ }^{54}$ Globalization cannot be understood without addressing the translocality of social reproduction, including the cyclical emigration between countryside and city within countries such as Mexico.

The transfer of money from wealthy countries to poorer countries through remittances is also substantial (see Table 2), and there is also a transfer of money to poor rural villages from workers labouring in the large cities of Mexico and Latin America. In the context of village economies like the one in San Jerónimo, however, such transfers help feed, clothe and house many more people than if that money were spent on such goods in the wealthy countries or in the burgeoning cities of Latin America. The translocality of social reproduction is functional to the continued viability of globalized capitalism.

\section{Conclusion}

The absolute number of rural residents is steadily increasing in most Latin American countries, despite the declining economic viability of agriculture. Rural communities rely less and less on farming to support themselves; emigration, craft-production and off-farm labour are more and more important to rural livelihood. The Mexican villages of Santa Fé and San Jerónimo exemplify this strategy. Although once important, agriculture is now the principal occupation of only a small number of people in each community, and the area devoted to agriculture is much less than in the past. Translocality is now a characteristic of rural life in these villages. Remittances from emigration to the United States, income from selling pottery town-to-town and wages from stints of labour outside the community provide important supplements to the livelihood of each community.

The production of nature thesis, enriched by greater attention to the simultaneous production of culture, suggests that people constantly produce culture through everyday activities of production and consumption. Individuals construct their identities as members of communities in specific cultural contexts. As they perform those identities, they help to produce specific cultures. The local production of culture, however, is shaped and constrained by relations of power, such as the international political economy of agriculture. Remittance-generating emigration is one of the ways to resist that power, because it permits the survival of rural communities and the reproduction of cultural contexts. This view of culture helps explain the continued presence of people like the villagers of Santa Fé and San Jerónimo, in places where the economic rationality of their habitation is suspect. ${ }^{55}$

As they produce culture, villagers produce nature, and they access the resources of locally produced nature to accomplish their own social reproduction. Using their own labour, for example, they provide themselves with wood from the forest for building their own shelters, cooking their own food and firing pottery. Through their communities they gain access to space for housing, and perhaps a space for planting maize. They make use of the resources of produced nature to maintain as much control 
as possible over their own social reproduction. They do not cede control over their own social reproduction to the market or the government, but instead keep it in the household and community.

Although the details vary considerably from place to place, the world is full of people like the rural Mexicans who stay put, people who stubbornly enact lives different from the ones suggested by the economic relationships of global capitalism, people who maintain identities more complex than those of peasant, proletarian or capitalist entrepreneur. Such people also produce nature as they go about the activities that produce culture, and nature shapes the process even as it is transformed by the process.

\section{Acknowledgements}

I gratefully acknowledge Mort Winsberg for compiling the data in Table 1. Mike Uzendoski pointed out some useful readings. Barney Warf and two anonymous reviewers provided constructive criticism of an earlier version of this manuscript. Don Mitchell's insightful comments and encouragements were especially useful. I also thank Kenneth Olwig for his comments on an earlier version of this manuscript. Funding for the fieldwork referenced in this article came from William and Jane Fortune through the Princeton Environmental Institute. I also owe intellectual debts to the staff of Grupo Interdisciplinario de Tecnologia Rural Apropiada AC (GIRA) as well as to community members and authorities of Santa Fé de la Laguna and San Jerónimo Purenchécuaro. I gratefully acknowledge David Barkin's influence and leadership in formulating many of the questions I explore here.

\section{Notes}

1 I choose to write 'translocal' instead of 'transnational' to avoid evoking the image of the increasingly large body of people who hold more than one passport. The term is also open to broader interpretations of rural people who patch together livelihoods through activities that take place in many different locales in the same country, including periods of work in urban areas or areas of commercial agriculture distant from their rural villages.

2 See, e.g. A. J. Bebbington and S. P. J. Batterbury, 'Transnational livelihoods and landscapes: political ecologies of globalization', Ecumene 8 (2001), pp. 369-80. Several other articles in that issue also develop the theme of transnational livelihoods. See also A. J. Bebbington, 'Reencountering development: livelihood transitions and place transformations in the Andes', Annals of the Association of American Geographers 90 (2000), pp. 495-520.

3 V.M. Juan Martinez, 'Migrantes y combate a la pobreza', Noticias (Oaxaca City daily newspaper), (2 Aug. 2003), no. 9549; L. Fink, The Maya of Morganton: work and community in the nuevo new south (Chapel Hill, University of North Carolina Press, 2003). The 'gentrified landscapes' citation is from B. Jokisch, 'Migration and agricultural change: the case of smallholder agriculture in highland Ecuador', Human ecology 30 (2002), p. 525.

4 See C. Katz, 'Vagabond capitalism and the necessity of social reproduction', Antipode' 33 (2001), pp. 709-28. 
5 This paper revisits my previous research on social and forest change in a small rural area of Mexico, work originally inspired by political-ecological theories of land use change, common property theory and local knowledge in development. In answer to a call for papers revisiting Margaret FitzSimmons' challenge to better integrate nature into geographical analysis for an AAG conference, I applied the idea of a 'social production of nature' to this work. Together with on-going conversations with David Barkin, that approach pushed me to perceive more clearly the ways in which rural Mexicans take advantage of craft production and cyclical emigration to ensure their own physical and cultural reproduction despite the declining viability of agriculture. Here I will argue that their labour in nature - and thus their role in changing vegetation - reflects an active process of cultural production. At the same time, their labour in the Mexican countryside facilitates life in cities far away. FitzSimmons' challenge is in M. FitzSimmons, 'Guest editorial', Environment and planning D: society and space 7 (1989), pp. 1-3; M. FitzSimmons, 'The matter of nature', Antipode 21 (1989), pp. 106-20.

6 World Bank President J. Wolfensohn, cited in 'World Bank chief scolds rich nations', New York Times (23 Sept. 2003). See also World Bank, 'Cutting agricultural subsidies', (20 Nov. 2003), available at: http://web.worldbank.org/WBSITE/EXTERNAL/NEWS/0 content MDK:20076497 menuPK:34459 pagePK:64003015 piPK:64003012 theSi-

tePK:4607,00.html In the US, the electoral strategies of George W. Bush's team increased US farm subsidies by $\$ 40$ billion in 2002, and electoral politics precluded discussion of those farm subsidies in the WTO talks in Cancun, according to E. Becker "Coming US vote figures in walkout at trade talks', New York Times (16 Sept. 2003), available at: http://query.nytimes. com/gst/abstract.html?res = F00816FF3C5E0C758DDDA00894DB404482.

7 See J. Vidal and D. Munk, 'Farmer who got a hearing by paying the ultimate price', Guardian (12 Sept. 2003), available at: http://www.guardian.co.uk/wto/article/0,2763,1040297,00.html. J. Brooke. 'Farming is Korean's life and he ends it in despair', New York Times (16 Sept. 2003), available at: http://query.nytimes.com/gst/abstract.html?res = F60711F93D5E0C758DD DA00894DB404482.

8 Pew Hispanic Center, Remittance senders and receivers: tracking the transnational channels (Washington, DC, Pew Hispanic Center, 2003), pp. 1-19, available at: http://www.pewhis panic.org/index.jsp.

9 D. Barkin, 'The reconstruction of a modern Mexican peasantry', Journal of peasant studies 30 (2002), pp. 73-90; D. Barkin, Distorted development: Mexico in the world economy (Boulder, Co, Westview Press, 1990); D. Myhre, 'The Achilles' heel of the reforms: the rural finance system', in W. Cornelius and D. Myhre, eds, The transformation of rural Mexico: reforming the Ejido sector (San Diego, Center for US-Mexican Studies at the University of California, San Diego, 1998), pp. 39-65.

10 For useful data tables of Mexican maize prices since 1970, see Barkin, 'Reconstruction'.

11 Not only does US maize production enjoy superior economies of scale and technology, it is also heavily subsidized. The US maize sector is the largest single recipient of US government payments, and the effective subsidy of maize exports to Mexico is on the order of $\$ 105$ to $\$ 145$ million annually. See Oxfam, Dumping without borders: how US agricultural policies are destroying the livelihoods of Mexican corn farmers (Boston, Oxfam, 2003), available at: http:// www.oxfam.org/eng/policy_pape_corn_dumping.htm

12 See Barkin, 'Reconstruction'.

13 Cited in ibid., pp. 81 and 88. In 2002 the Mexican Secretary of Agriculture was quoted saying the challenge to grain producers is either to become 'efficient' according to 'international standards,' or to do something else: El financiero (21 Nov. 2002). 
14 A. de Janvry and E. Sadoulet, 'Income strategies among rural households in Mexico: the role of off-farm activities', World development 29 (2001), pp. 467-80.

15 Barkin, 'Reconstruction', p. 89.

16 The Mexican census of 2000 shows 39\% of Mexicans live in towns of less than 15000 inhabitants and 25.4\% live in settlements smaller than 2500. See Barkin, 'Reconstruction', p. 89.

17 For an argument that the presumption of deforestation is a misreading of the Mexican landscape, see D. Klooster, 'Beyond deforestation: the social context of forest change in two indigenous communities in highland Mexico', Yearbook, Conference of Latin Americanist Geographers (Journal of Latin American Geography) 26 (2000), pp. 47-59. For a comparison of professional silviculture and local forest use practices, see D. Klooster, 'Towards adaptive community forest management: integrating local forest knowledge with scientific forestry', Economic geography $\mathbf{7 8}$ (2002), pp. 42-70. For a discussion of how the political economy of agriculture in North America might be affecting fields and forests in long-settled regions of highland Mexico, see D. Klooster, 'Regional forest transitions in highland Mexico? The importance of local institutions in a globalized countryside', Professional geographer 55 (2003), pp. 227-237.

18 D. Brand, Quiroga: a mexican municipio (Washington, DC, Smithsonian Institution, 1951).

19 I use pseudonyms throughout.

20 Brand, Quiroga.

${ }^{21}$ For a discussion of pottery production in Santa Fé, see R.C. West, Cultural geography of the modern tarascan area (Washington, DC, Smithsonian Institution, 1947); A. Gortaire Iturralde, Santa Fé: presencia de un pueblo bospital (Mexico City, Universidad Iberoamericana, 1971); J. Navia and S. Ochoa, Las pequeñas empresas artesanales en la región Purépecha: el caso de las alfarerías (unpublished MS, Patzcuaro, Grupo Interdisciplinario de Tecnología Rural Apropiada AC, 1998); J. Durston, Organización social de los mercados campesinos en el centro de Michoacán (Mexico City, Instituto Nacional Indigenista, 1992); O. Masera, J. Navia, G. Ruiz, J.C. Cedeno, S. Ochóa, J.L. Fabián, D. Bautista, and I. Alejandre, Documento comunitario: uso de la leña en Santa Fé de la Laguna, Michoacán (unpublished MS, Patzcuaro, México, Grupo Interdisciplinario de Tecnología Rural Apropiada AC, 1997).

22 Klooster, 'Beyond deforestation'.

23 For population and livelihood data, see ibid. San Jerónimo is so famous as a source of emigration that the Economist featured it in a survey of the Mexican economic and social situation: 'Survey Mexico: home and away', Economist (28 Oct. 2000), p. 8.

${ }^{24}$ In the Mexican context, indigenous and non-indigenous rural peoples share many cultural traits. See G. Bonfil Batalla, Mexico profundo: una civilización negada (Mexico City, Grijalbo, 1987). For example, even though just $20 \%$ of people in the Lake Patzcuaro basin speak Purepecha, some observers consider $60 \%$ or more of the inhabitants of this region to be fundamentally indigenous. See V. M. Toledo, 'Patzcuaro's lesson: nature, production, and culture in an indigenous region of Mexico', in M. Oldfield and J. B. Alcorn, eds, Biodiversity: culture, conservation, and ecodevelopment, (Boulder, CO, Westview Press, 1991), pp. 147-71. Interview with Rudelia.

26 Klooster, 'Beyond Deforestation'.

27 J. Martínez Luna, ¿Es la comunidad nuestra identidad?', in A. Warman and A. Argueta, eds, Movimientos indigenas contemporáneos en México (Mexico City, Centro de Investigaciones Interdisciplinarias en Humanidades, UNAM, 1993), 161. My translation. In Oaxaca, faena is called tequio.

28 Klooster, 'Beyond deforestation'. 
29 For critics, the production of nature approach over emphasizes production at the expense of other processes which also socialize nature, and in which productive processes are always embedded. They also point out that the approach is one-sided, showing much greater interest in how capitalism produces nature and much less in how produced nature affects capitalism. Much of the recent writing in the 'production of nature' thesis deals with events at the core of global capitalism, including the growth of cities, the commodification of seeds and genetic engineering. See N. Castree, 'Marxism, capitalism, and the production of nature', in N. Castree and B. Braun, eds, Social nature: theory, practice, and politics (Malden, MA, Blackwell, 2001), pp. 189-207. For proponents, the thesis relieves the analyst from continually portraying the human domination of nature. It opens up the history of nature to retrospective examination and future political agency. See N. Smith, 'Nature at the millennium: production and reenchantment', in B. Braun and N. Castree, eds, Remaking reality (New York, Routledge, 1998), pp. $271-85$.

30 K. Marx, Capital, cited in N. Smith and P. O'Keefe, 'Geography, Marx and the concept of nature', Antipode 12 (1989), pp. 30-9.

31 Smith, 'Production and re-enchantment'.

32 C. Geertz, The interpretation of cultures (New York, Basic Books, 1973), p 10.

33 Ibid., p. 5.

34 A. Appadurai, Modernity at large: cultural dimensions of globalization (Minneapolis, University of Minnesota Press, 1996), p. 184.

35 Ibid., pp. 180-81. Although Appadurai expresses the idea of producing locality quite nicely here, he makes too little of the material basis of cultural production and too much of the global flows of cultural symbols in his argument, and he underplays the role of relations of power in his depictions of globalization.

36 Geertz, Interpretation, p. 49.

37 Ibid.

38 Ibid., p. 52.

39 M. Douglas, How institutions think (Syracuse, NY, Syracuse University Press, 1986), p. 128.

40 Appadurai, Modernity.

41 D. Mitchell, 'There's no such thing as culture: towards a reconceptualization of the idea of culture in geography', Transactions of the Institute of British Geographers 20 (1995), pp. 10216.

42 A semiotic definition of culture, with an emphasis on its continual production through action, and hence its fragility and malleability, permits us to understand the relationship between culture and identity without slipping into a 'culture makes them do it' version of racism. It helps us maintain a critical stance, as Mitchell demands that we do, by avoiding explanations that rely on 'culture' in the same way critical geographers avoid obfuscations based on an ideology of 'nature'. Just as a critical geography denies that social structures occur because they are natural, it must also deny that social structures occur because they are cultural.

43 S. W. Mintz, Sweetness and power (New York, Viking Penguin, 1985), p. 185.

44 Ibid., p. 13.

45 Klooster, 'Beyond deforestation'.

46 Masera et al., Documento comunitario; Navia and Ochoa, Empresas artesanales; Klooster, 'Beyond deforestation'.

47 O. R. Masera, B. D. Saatkamp and D. M. Kammen, 'From linear fuel switching to multiple cooking strategies: a critique and alternative to the energy ladder model', World development 28 (2000), pp. 2083-2103. 
48 Forest inventories were conducted as part of a programme to improve community forest management in 1998. The same forester employed similar methods in both communities. See Klooster, 'Beyond deforestation'; 'Adaptive management'.

49 Social relations of production at the regional, national and international scales are also immanent in the Santa Fé/San Jerónimo landscape. These include the power of state agencies and agricultural multinationals that have made policy choices condemning food production in regions like this one. They also include Mexican forest laws and forest management science which sanction either forest preservation or industrial logging, but not community fuel-wood management. See Klooster, 'Adaptive management'. The forest landscape also reflects the characteristics of social organization between Santa Fé and the neighbouring village of Quiroga. Historically, woodcutters from the neighbouring town of Quiroga cut in the forest of Santa Fé to supply carpentry workshops. Their intense cutting of large pines, fir and madrone continued through the 1970s, until Elpidio Dominguez Castro led his fellow Santa Fé villagers in a campaign to expel them and re-establish local control over their lands and forest. Twenty years later, however, Santa Fé's forest still reflects this history of wood theft. (San Jerónimo escaped this history, mainly because of its greater distance from Quiroga.) For the history of struggle between Santa Fé and Quiroga, see Gortaire Iturralde, 'Santa Fe'. E. Zárate Hernández, Los señores de la Utopiá (Zamora, Michoacán, El Colegio de Michoacán/CIESAS, 1993); N. Dimas Huacúz, Forma y composición de la tenencia de la tierra en Santa Fé de la Laguna (Mexico City, Secretaría de Educación Pública and Instituto Nacional Indigenista, 1982).

50 Klooster, 'Adaptive management'.

51 For a discussion of succession and disturbance in Mexican pine-oak forests, see L. C. Snook and P. C. Negreros, 'Effects of Mexico's selective cutting system on pine regeneration and growth in a mixed pine-oak (Pinus-Quercus) forest', in Current topics in forest research: emphasis on contributions by women scientists. Proceedings of a national symposium (Gainesville, FL, US Forest Service, 1986); B. T. Styles, 'Genus Pinus: A Mexican Purview', in T. P. Ramamoorthy, R. Bye, A. Lot and J. Fa, eds, Biological diversity of Mexico: origins and distribution (New York, Oxford University Press, 1993), pp. 397-420

52 Klooster. 'Adaptive management'.

53 Katz, 'Vagabond capitalism', p. 711.

54 Ibid., p. 710.

55 An extremely strong version of this argument is difficult to sustain. People do not remain in rural areas only because they value the cultures they produce there. In many places, the permanent crisis of agriculture is mirrored by an urban crisis of limited opportunities and difficult living conditions. Furthermore, the case study illustrating the argument is from Mexico, which has a substantial domestic economy, a long border with the United States and a history of emigration to the US. In addition, the case study villages contain indigenous, Purepecha-speaking people, and such people are arguably more likely to protect their differences from other peoples by maintaining their communities and territories. On the other hand, indigenous peoples constitute substantial components of the rural populations of several Latin American countries with strong patterns of emigration to the US and other wealthy countries. Furthermore, even non-indigenous Latin American rural cultures often contain a mixture of indigenous and other cultural traits, so the example developed here probably has wide applications. Additional observations in Latin America and elsewhere in the developing world are needed to reveal the extent and importance of cultural conservation in the persistence of rural populations with greater precision. 